\title{
PRODUCTION OF AMYLASE ENZYMES BY FILAMENTOUS FUNGI
}

Darwish, Soumia M. I. ; M. Afifi ${ }^{2}$; Eman Mostafa ${ }^{3}$ and

A. A. El-Shanawany ${ }^{2}$

1 Food Science and Technology Dept., Fac. of Agric., Assiut Univ., Egypt

${ }^{2}$ Botany \& Microbiology Dept., Fac. of Science, Al-Azhar Univ., Assiut branch, Assiut, Egypt.

${ }^{3}$ Botany Department, Fac. of Science, Assiut Univ., Egypt

\begin{abstract}
Fifty-two out of one hundred and forty-four isolates of filamentous fungi were recorded as amylase producer, but with different degrees, on solid plate method. Chemical constituents of potato waste samples (collected from the Chpis' Factory for Food Industries, Assiut, Egypt) were determined by chemical analysis. Twelve isolates (eight highly producer isolates and four isolates isolated from potato wastes) were screened for amylase production on potato wastes. Aspergillus flavus 443 was recorded as the best enzyme producer on potato wastes and synthetic medium. The best environmental and nutritional conditions for amylase production by Aspergillus flavus 443 were : [50 gm of potato wastes with $10 \mathrm{ml}$ distilled water, manitol (1\%) as a carbon source, casein $(1 \%)$ as a nitrogen source, $\mathrm{pH} 5$ and the medium was incubated at $40^{\circ} \mathrm{C}$ for three days ).
\end{abstract}

\section{INTRODUCTION}

Amylases are important extracellular enzymes ; stabile over a wide range of $\mathrm{pH}$ values and thermostabile enzymes employed in the starch processing industries for the hydrolysis of starch into simple fermented sugar (glucose) (Akpan et al., 1999).

During the last decade, an increased attention was paid to the use of various agro- industrial wastes in solid-state fermentation (SSF) by filamentous fungi (Pandey \& Soccol, 2000 and Pandey et al., 1999; 2000a; 2001).It has been reported that SSF is the most appropriate process in developing countries due to the advantages it offers (Carrizales \& Jappe, 1986; Alva et al., 2007).

Fungal amylases are find potential application in a number of industrial processes such as in food, baking, brewing, detergent, textile pharmaceutical, confectionaries, paper, skin production, fruit processing and juice production, tea, coffee and chocolate syrups industries. With the advent of new frontiers in biotechnology, the spectrum of amylase application has expanded into many other fields, such as clinical, medical and analytical chemistry (Forgarty, 1983; Ibukun and Akindumila, 1998; Achi \& Njoku, 1992; Okolo et al., 1995 and Pandey et al., 2000a\&b). The pretreatment of the substrates from several fungi amylases were widely used in industry for production numerous products such as lipid production (Kaur and Worgan, 1982), organic acid like lactic acid (Huang et al., 2003\& 2005; Jin et al., 2003), production of fungal protein and amino acids (Jin et al., 1999), Ethanol 
(Gregg \& Sadder, 1995 and BBI, 2002) and biodeterioration of industrial paper (Rojas et al., 2008).

A cost reduction in amylase enzyme production can be achieved by using less expensive substrates, such as agro-industrial waste products (Hang and Woodams, 1984, 1985, 1987; Aravantinos-Zafiris et al., 1994; Khare et al., 1995; Pandey et al., 2000b; Vandenberghe, 2000a\&b; Soccol et al., 2003).

Potato tubers are abundant material that mainly contains fresh matter [moisture $(80 \pm 2 \%)$, starch $(18 \pm 2 \%)$, cellulose and hemicelluloses $(1.5 \pm 0.5 \%)$, glucose $(0.4 \pm 0.3 \%)$ and proteins $(2 \pm 1.5 \%)$ (Delgado et al., 2009).

Annual world production of Potato is around 300 million tons, and areas planted cover more than 18 million ha. Major producing countries and the world's share of production are (China, 20\%; Russia, 12\%; India, $8 \%$ and United States, 8\%) Delgado et al., (2009) . Potato is one of the most important crops grown in Egypt for local consumption, export and processing. The area cultivated with potatoes about 212,000 acres producing about 2.2 million tons, with an average of 10.5 tons per acre (Hegazy, 2009). Biotechnology industries demand potato (Solanum tuberosum) the best raw materials to prepare growth media for the fermentative processes (Liu \& Xu, 2008 and Delgado et al., 2009).

The present study is aimed to screening of numerous Egyptian fungal isolates (144) for amylase production on synthetic medium. Also, utilization; optimization and maximization of both nutrition and environmental condition affecting amylase production on potato wastes by the most highly producer isolates were studied.

\section{MATERIALS AND METHODS}

\section{I-Primary Screening of Isolates for Amylase Production \\ 1- Collection of different fungal isolates}

One hundred and forty-four isolates of filamentous fungi belonging to twenty two genera and fifty- five species in addition to two species varieties were tested for amylase production. These isolates were obtained from Botany Department, Faculty of Science, Assiut University, Egypt and AUMC (Assiut University Mycological Center). These isolates were isolated from different sources.

The isolates were maintained on slopes of Czapek's Dox agar medium (Smith \& Onions, 1983a\&b). Inoculums were prepared from a 7 day old culture in spore suspensions in $0.2 \%(\mathrm{VIV})$ aqueous Tween 80 . The $\mathrm{pH}$ was adjusted to 6.5 and incubated at $28+2 \stackrel{\circ}{\circ} \mathrm{C}$ for ten days.

\section{2-Enzyme assay}

The tested isolates were propagated firstly on PDA medium at $37^{\circ} \mathrm{C}$ for 3-4 days. Inoculums of fungal isolates were transferred from PDA plates and inoculated on agar medium (gm / L) [(NH4)2 SO4, 0.2; KH2PO4, 0.2; starch, 1.0 and agar agar, 15]. Triplicate cultures were incubated for 72 hours at $37 \stackrel{\circ}{\circ}$. Detection the amylase production by using $2 \%$ iodine solution was 
added to the Petri dishes to detect the clear zones around the colonies against the blue background of substrate. (Pandey,1991; 1992). Select the fungus with the greatest hydrolytic activity for further investigations.

\section{II- Potato Wastes}

\section{a- Collection of samples}

$500 \mathrm{~g}$ of each sample of Potato solid wastes were collected from Assuit Manufactory at Assuit governorates. The samples were placed in a double sterile polyethylene bags (to minimizes the loss of water content and provides sufficient aeration), sealed, transferred immediately to the laboratory, kept in cool place $\left(5^{\circ} \mathrm{C}\right)$ until amylase screening .The Chemical analysis and moisture content of samples was directly determined.

\section{b- Chemical Analysis of Potato Wastes}

Moisture content, crude fat, ash, crude protein, crude fiber contents were determined according to standard methods A.O.A.C. (1990).

\section{C-Determination of Mineral}

\section{1- Digestion of samples}

Five grams from each sample was digested by using a mixture of nitric and perchloric acids (Abdel-Akher et al., 1959 and Khan et al. 1996).

\section{2- Estimation of Micro and Macro Elements}

Micro elements (Fe, Mn, $\mathrm{Cu}$, and $\mathrm{Zn}$ ) and macro elements ( $\mathrm{Na}, \mathrm{K}, \mathrm{Ca}$, $\mathrm{Mg}, \mathrm{S}$ and $\mathrm{P}$ ) were analyzed using atomic absorption spectrophotometer (model GBC $906 \mathrm{AA}$ ).

III- Amylase Production by the Best Producer Isolates on Potato Wastes The most eight highly producer isolates and four isolates isolated from potato wastes were studied (Table III). Screening of fungal species for amylase production on potato wastes (substrate $10 \mathrm{~g}$ and $10 \mathrm{ml}$ water for resign moisture content in 250 conical flask, sterilized at $121 \stackrel{\circ}{\circ} \mathrm{C}$ for 15 minutes, inoculated by two methods:-

$1 \mathrm{ml}$ spores suspension, incubated at $28 \stackrel{\circ}{\circ} \mathrm{C}$ for 5 days and examined by addition of $10 \mathrm{ml}$ of sterilized distilled water, mixed and then filtered. The filtrate has used for detection the residue of unused reducing sugar and crude amylase enzyme.

Inoculums in the center of the Petri dish by the tested isolates and the plates were incubated at $28^{\circ} \mathrm{C} 5$ days for determined the production of amylase by clear zone which discussed above (Alva, et al., 2007). The best producer isolate was selected for further investigation.

\section{Determination of reducing sugars}

The estimation of starch was carried out using the iodine colorimetric method as described by Tomas and Chamberlain (1980). Reducing sugars were estimated by the dinitrosalicylic acid method using glucose as the standard (Miller, 1959). In the present study, the reducing sugars were described as the sum of the formation due to saccharification and consumption due to fermentation (Abu, et al., 2005). 
IV- Optimization And Maximization of Nutritional And Environmental Conditions Affecting Amylase Production By Aspergillus flavus (443) On Potato Wastes

a- Incubation period

To study the effect of incubation period on enzyme production at $28^{\circ} \mathrm{C}$ in 250 conical flask- substrate $10 \mathrm{~g}$. The enzyme substrate reaction mixture was incubated for different incubation periods (3,5 and 7 days) and enzyme production was recorded.

b-Amount of Substrate Used

Effect of amount of substrate used on enzyme production was measured at different concentrations of potato wastes in the reaction mixture from 1.0 to $50 \mathrm{gm}$.

c-pH value : Effect of $\mathrm{pHs}$ on amylase production was determined by incubating the reaction mixture at pHs values ranging from 3.0 to 11 by using $\mathrm{Na} \mathrm{OH}-\mathrm{HCl}$ one normal.

d-Temperature :Optimum temperature for amylase production was determined by conducting the assay at different temperatures ranging from 10 to $60 \stackrel{\circ}{\circ}$.

e-Nitrogen source: Stimulation effect of five different nitrogen sources (1.0 $\%$ from each of peptone, urea, ammonium phosphate, ammonium sulphate and casein) on $10 \mathrm{gm}$ potato wastes on amylase production was studied.

f-Carbon source :Stimulation effect of seven different carbon sources (1.0\% from each of lactose, fructose, glucose, maltose, manitol, sucrose and starch) on $10 \mathrm{gm}$ potato wastes on enzyme production was studied.

\section{RESULTS AND DISCUSSION}

One hundred and forty-four isolates of filamentous fungi belonging to twenty-two genera and fifty-five species in addition to two species varieties were tested for production of amylase on synthetic medium. Fifty-two isolates were recorded as amylase enzyme producer (Table I) and classified into 3 categories. Three species from Aspergilli only have highly productivity and these were Aspergillus flavus 443, A. flavus var. columnaris961 and A.oryzae42 (Table I) . In previous studies Aspergillus flavus and A.oryzae are well known as amylase producers on different substrate as recorded by several workers [Yabuki et al., 1977; Erratt et al., 1984; Arnesen et al., 1998; Viswanathan and Surlikar, 2001; Francis et al., 2003; Nirmala \& Muralikrishna, 2003 ; Ramachandran et al., 2004; Kammoun et al., 2008 and Djekrif-Dakhmouche et al., 2006] .

Twenty-four isolates representing 25 isolates have moderate productivity (Table I) Aspergillus seven isolates, Penicilli, six isolates eleven isolates, two isolates from Acremonium strictum; Alternaria alternata and others (Table I) .

Twenty-four isolates representing fifteen species and one variety have low productivity of which Aspergillus fumigatus var. albus, A. flavipes, $A$. sydowii and $A$. versicolor; Penicillium funiculosum $P$. purpurogenum and others (Table 1). It is worthy to mention that some isolates of the same 
species variable degrees of amylase production and this depend on the individual isolates.

Table (I): Screening the $\mathbf{1 4 4}$ isolates of filamentous fungi for amylase production on Synthetic Medium

\begin{tabular}{|c|c|c|c|c|c|c|}
\hline \multirow{2}{*}{$\begin{array}{l}\text { Genus ; species } \\
\text { species variety }\end{array}$} & \multirow{2}{*}{$\begin{array}{c}\text { No. of isolates } \\
\text { tested }\end{array}$} & \multicolumn{3}{|c|}{ +ve isolates } & \multirow{2}{*}{$\begin{array}{c}\text { Total +ve } \\
\text { isolates }\end{array}$} & \multirow{2}{*}{$\begin{array}{c}\text {-ve } \\
\text { isolates }\end{array}$} \\
\hline & & Low & Modrate & High & & \\
\hline Absidia corymbifera & 1 & - & - & - & - & 1 \\
\hline Acremonium. strictum & 3 & 1 & 2 & - & 3 & - \\
\hline Alternaria alternata & 3 & - & 1 & - & 1 & 2 \\
\hline Aspergillus & 36 & 6 & 6 & 3 & 15 & 21 \\
\hline A. alutaceus & 2 & - & 1 & - & 1 & 1 \\
\hline A. candidus & 2 & - & 1 & - & 1 & 1 \\
\hline A. Carneus & 2 & - & 1 & - & 1 & 1 \\
\hline A. clavatus & 1 & - & - & - & - & 1 \\
\hline A. flavus & 2 & - & - & 1 & 1 & 1 \\
\hline A. flavus var. columnaris & 2 & - & - & 1 & 1 & 1 \\
\hline A. fumigatus & 3 & - & - & - & - & 3 \\
\hline A. fumigatus var. albus & 4 & 2 & - & - & 2 & 2 \\
\hline A. niger & 4 & - & - & - & - & 4 \\
\hline A. oryzae & 1 & - & - & 1 & 1 & - \\
\hline A. sydowii & 3 & 3 & - & - & 3 & - \\
\hline A. tamarii & 2 & - & - & - & - & 2 \\
\hline A. terreus & 1 & - & - & - & - & 1 \\
\hline A. terricola & 1 & - & 1 & - & 1 & - \\
\hline A. ustus & 3 & - & 2 & - & 2 & 1 \\
\hline A. versicolor & 3 & 1 & - & - & 1 & 2 \\
\hline Cladosporium & 6 & - & 1 & - & 1 & 5 \\
\hline Cl. cladosporioides & 3 & - & - & - & - & 3 \\
\hline Cl. herbarum & 3 & - & 1 & - & 1 & 2 \\
\hline Cochliobolus & 6 & 2 & 2 & - & 4 & 2 \\
\hline C. lunatus & 3 & - & 1 & - & 1 & 2 \\
\hline C. spicifer & 3 & 2 & 1 & - & 3 & - \\
\hline Emerciella & 2 & - & - & - & - & 2 \\
\hline E. nidulans & 1 & - & - & - & - & 1 \\
\hline E. stellata & 1 & - & - & - & - & 1 \\
\hline Fennelia & 3 & 2 & 1 & - & 3 & - \\
\hline F. flavipes & 1 & 1 & - & - & 1 & - \\
\hline F. nivea & 2 & 1 & 1 & - & 2 & - \\
\hline Fusarium & 17 & 2 & 1 & - & 3 & 14 \\
\hline$F$. incarnatum & 1 & - & - & - & - & 1 \\
\hline F. moniliforme & 3 & 1 & - & - & 1 & 2 \\
\hline F. oxysporum & 3 & - & 1 & - & 1 & 2 \\
\hline F. proliferate & 1 & 1 & - & - & 1 & - \\
\hline F. samboucusum & 3 & - & - & - & - & 3 \\
\hline F. semitectum & 3 & - & - & - & - & 3 \\
\hline F. solani & 3 & - & - & - & - & 3 \\
\hline Gliocladium & 5 & - & 2 & - & 2 & 3 \\
\hline G. . catenulatue & 1 & - & 1 & - & 1 & - \\
\hline G. roseum & 4 & - & 1 & - & 1 & 3 \\
\hline
\end{tabular}


Darwish, Soumia M. I. et al.

Table (I): Continue

\begin{tabular}{|c|c|c|c|c|c|c|}
\hline \multirow{2}{*}{$\begin{array}{l}\text { Genus ; species and species } \\
\text { variety }\end{array}$} & \multirow{2}{*}{$\begin{array}{l}\begin{array}{l}\text { No. of isolates } \\
\text { tested }\end{array}\end{array}$} & \multicolumn{3}{|c|}{ +ve isolates } & \multirow{2}{*}{$\begin{array}{l}\text { Total +ve } \\
\text { isolates }\end{array}$} & \multirow{2}{*}{$\begin{array}{c}\text {-ve } \\
\text { isolates }\end{array}$} \\
\hline & & Low & Modrate & High & & \\
\hline Macrophomina phaseolina & 3 & - & 1 & - & 1 & 2 \\
\hline Mucor circinelloides & 3 & - & - & - & - & 3 \\
\hline Myrothecium verrucaria & 1 & - & - & - & - & 1 \\
\hline Neosartorya fisherii & 4 & - & - & - & - & 4 \\
\hline Paecilomyces variotii & 3 & 1 & - & - & 1 & 2 \\
\hline Penicillium & 32 & 8 & 7 & - & 15 & 17 \\
\hline P.aurantiogriseum & 3 & - & 1 & - & 1 & 2 \\
\hline$P$. brevicompactum & 3 & - & - & - & - & 3 \\
\hline$P$. chrysogenum & 5 & 1 & 1 & - & 2 & 3 \\
\hline P. citrinum & 4 & 1 & 2 & - & 3 & 1 \\
\hline P. cyclopium & 3 & - & 1 & - & 1 & 2 \\
\hline P. funiculosum & 4 & 4 & - & - & 4 & - \\
\hline$P$. italicum & 2 & - & - & - & - & 2 \\
\hline$P$. janthinellum & 3 & 1 & 1 & - & 2 & 1 \\
\hline P. oxalicum & 2 & - & 1 & - & 1 & 1 \\
\hline$P$. purpurogenum & 3 & 1 & - & - & 1 & 2 \\
\hline Scopulariopsis brevicaulis & 4 & 2 & - & - & 2 & 2 \\
\hline Stachybotrys chartarum & 2 & - & - & - & - & 2 \\
\hline Syncephalastrum racemosum & 2 & - & - & - & - & 2 \\
\hline Trichoderma. harzianum & 3 & - & - & - & - & 3 \\
\hline Trichothecium roseum & 3 & - & - & - & - & 3 \\
\hline Trichurus spiralis & 2 & - & 1 & - & 1 & 1 \\
\hline Total isolates & 144 & 24 & 25 & 3 & 52 & 92 \\
\hline Number of species & & & $55+2$ val & riety & & \\
\hline Number of genus & & & 22 & & & \\
\hline
\end{tabular}

$\mathrm{H}=$ Isolates which have highly productivity (from 41 to $60 \mathrm{~mm}$ clear zone diameter)

M = Isolates which have moderate productivity (from 21 to $40 \mathrm{~mm}$ clear zone diameter).

$\mathrm{L}=$ Isolates which have low productivity (from 1 to $20 \mathrm{~mm}$ clear zone diameter).

Several of the above species were previously recorded as amylase producers, but with different degrees, as reported by numerous researchers (Prescot \& Dunn, 1959 ; Ueda,1981; Hayashida \& Teramoto, 1986 ; Bunni et al., 1989; Jensen \& Olsen, 1992; Sudo et al., 1995; Okolo et al., 1995; Carlsen et al., 1996 a to c; Kaneko et al., 1996 ; Chadha et al., 1997; Arnesen et al., 1998; Goto et al., 1998 ; Nguyen et al., 2000 ; Pederson \& Nielson, 2000; Vishwanathan \& Surlikar, 2001; Aquino et al., 2003; Francis et al., 2003; Moreira et al., 2004 ; Kunamneni et al., 2005 ; Patel et al., 2005; Rahardjo et al., 2005 ; Samborska et al., 2005; Schwab , 2007; Afifi et al., 2008 and Rojas et al ., 2008 and several others) .

\section{Potato wastes}

Chemical analysis of potato solid wastes an abundant material that mainly contains $(\% \mathrm{dm})$ : were as flows moisture content $(77.0) \%$, crude protein $(2.52) \%$, crude fat $(0.13) \%$, Crude fiber (3.50), Ash $(5.31) \%$, carbohydrate (88. 54) \%. The micro and macro element in potato were widely varied (Fe, 87.75; Mn, 5.25; Cu, 11.45 ; Zn, 15.9 ; Na 1350 ; K, 11002; Ca, 2800; Mg, 1560; S ,2295 ;P, 2050 mg/ kg-1 dry mater) Table (II). These results almost in agreement with the results obtained by (Omemu, et al., 2005 and Delgado et al,. 2009). 
Table (II): Chemical Analysis of the Potato Solid Wastes.

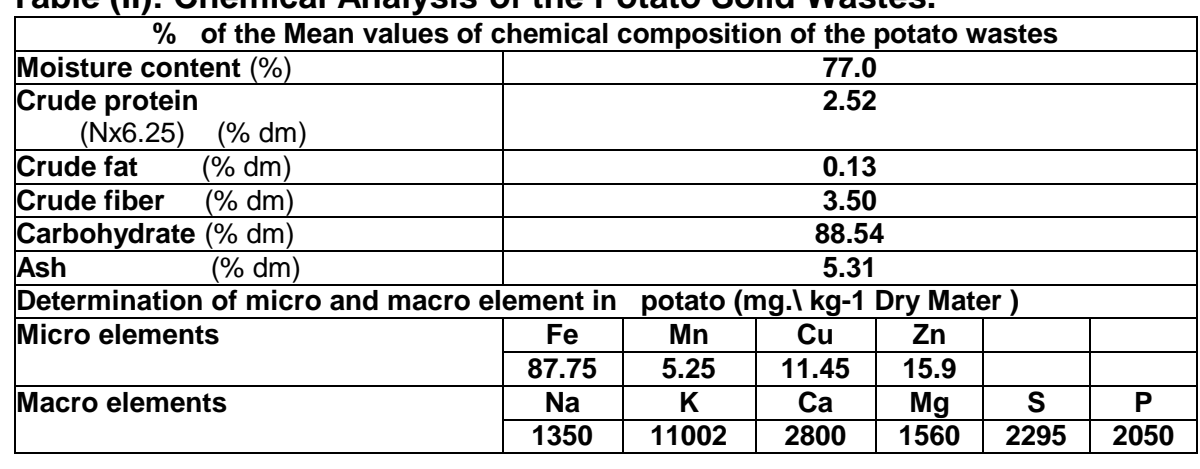

The screening results of twelve isolates [the most highly amylase producer isolates ( 3 and 5 of high and moderate productivity, respectively) on synthetic medium and four isolates isolated from potato wastes) for determined their ability to produced amylase enzyme on potato wastes as agro-industrial wastes are shown in Table (III). Of the recorded result, Aspergillus flavus443 was the best amylase producer on the synthetic medium and potato wastes medium. These isolate was selected for further study to optimization and maximization (nutritional and environmental factors) for amylase production.

Table (III): Screening of Twelve Isolates for Amylase Production on the Potato Wastes:-

\begin{tabular}{|c|c|c|c|c|}
\hline Serial no. & & $\begin{array}{l}\text { Tested fungal genus \& species } \\
\text { With No. of strain (AUCC) }\end{array}$ & $\begin{array}{c}\text { Reducing } \\
\text { sugars (g/L) }\end{array}$ & $\begin{array}{l}\text { Mean diameters of } \\
\text { clearing zone }(\mathrm{mm})\end{array}$ \\
\hline \multirow{8}{*}{$\begin{array}{l}\text { The Best } \\
\text { amylase } \\
\text { Producer } \\
\text { Isolates on } \\
\text { Synthetic } \\
\text { Medium }\end{array}$} & 1 & Aspergillus flavus fu3 $_{43}$ & 0.298 & 24.5 \\
\hline & 2 & A. flavus var columinaris 461 & 0.456 & 24.1 \\
\hline & 3 & A. oryza $_{42}$ & 0.702 & 20.5 \\
\hline & 4 & A. ustus 1450 & 0.730 & 19.5 \\
\hline & 5 & Cladosporium herbarum $_{3413}$ & 0.650 & 22.0 \\
\hline & 6 & Cochliobolus spicifer $_{143}$ & 1.140 & 14.0 \\
\hline & 7 & Gliochlodium catenulate $_{257}$ & 1.154 & 13.5 \\
\hline & 8 & Penicillium cyclopium $_{723}$ & 0.678 & 21.2 \\
\hline \multirow{4}{*}{$\begin{array}{l}\text { Isolates } \\
\text { Isolated From } \\
\text { Potato Wastes }\end{array}$} & 9 & Aspergfillus flavus ${ }_{\mathrm{MAF}}$ & 0.762 & 18.5 \\
\hline & 10 & A. niger & 0.762 & 18.5 \\
\hline & 11 & Fusarium moniliforme $\mathrm{s}$ & 1.154 & 13.5 \\
\hline & 12 & Fusarium $\mathrm{L}$ & 1.154 & 13.5 \\
\hline Control & & & 0.460 & 23.6 \\
\hline
\end{tabular}

Table (IV) shows that the best environmental factors for amylase production by Aspergillus flavus443 on potato wastes medium were: 3 days incubation period, $\mathrm{pH} 5$ and $40{ }^{\circ} \mathrm{C}$ incubation temperature. Our results are almost in agreement with previous studies on amylase production by some species of filamentous fungi by (Prescot \& Dunn, 1959; Yamasaki et al., 1977; Tomas \& Chamberlain,1980; Bergmann et al.,1988; Hayoshida et al., 1988 ;Okolo et al.,1995 ;Abu et al., 2005 ; Haq et al., 2006 ;Alva,et al. ,2007; Mona Gouda \& Elbahloul ,2008 ; Rojas et al.,2008 and Delgado et al.,2009). 
Darwish, Soumia M. I. et al. 
Also Stimulation of amylase production was obtained when manitol (1.0 $\%$ ) or sucrose (1.0\%) were used as a carbon source (from1.2 to 25.5 or 28 $\mathrm{mm}$ clear zone and 1.2 to $0.2 \mathrm{gm} / \mathrm{L}$ reducing sugars) and casein followed by ammonium sulphate, urea, ammonium phosphate and peptone as nitrogen sources (21, 75- $25.5 \mathrm{~mm}$ clear zone; and $0.65-0.27 \mathrm{gm} / \mathrm{L}$ reducing sugars) as nitrogen sources.

The best amount of potato waste was used for amylase production was $15-50 \mathrm{gm}$ waste in $250 \mathrm{ml}$ conical flask pluss $10 \mathrm{ml}$ sterilized water (27.3 $-28.0 \mathrm{~mm}$ clear zone , $0,23-0.20 \mathrm{gm} / \mathrm{L}$ reducing sugars).

Several workers studied the effect of some carbon and nitrogen sources for amylases production by several fungi such as some members of Aspergillus, Penicillium and Trichoderma (Kammoun et al., 2008 and Mona Gouda \& Elbahloul ,2008).

Haq et al., (2006) found that Trichoderma viride was further optimized for enhanced production and increased in amylase production was observed when sweet potato starch was used as carbon source. No enhancement in production was taken place by replacing ammonium sulphate with any other nitrogen source. USDA (2008) and Delgado et al.(2009) observed that potato starch is very suitable substrate for amylase production by several fungi .

In conclusions, potato waste (as agro-industrial waste) is economically important and can be used as a substrate for amylase production by several fungi and enzyme was used in numerous industries such as food and health care, chemical industry, polymer synthesis, pharmaceutical industry and the energy sector.

\section{ACKNOWLEDGEMENTS}

We would thank Prof. Dr. Moubasher, A.H. the head of the an AUCC (Assiut University Mycological Center) Assiut University, Egypt for supplying the tested isolates samples and Chpis' Factory for Food Industries, Assiut, Egypt for supplying samples.

\section{REFERENCES}

A.O.A.C. (1990) Official Methods of Analysis. 14th ed. Association of Official Analytical Chemists. Washington, D.C.

Abdel-Akher, M.; J.K. Hamilton and F. Smith (1959) The reduction of sugars with sodium borohydride. J. Am. Chem. Soc. 73: 469-4692.

Abu, E.A.; S.A. Ado and D.B. James (2005) Raw starch degrading amylase production by mixed culture of Aspergillus niger and Saccharomyces cerevisae grown on sorghum pomace. African Journal of Biotechnology. 4 (8): 785-790.

Achi , O.K. and A. Njoku-Obi (1992) Production of raw starch saccharification amylase by Bacillus alvei grown on different agricultural substrates. World J. Microbiol. Biotechnol. 8: 206-207.

Afifi, A.F. ; E.M. Kamel; A.A. Khalil; M.A. Foaad; E.M Fawzi and M.M. Houseny (2008) Purification of characterization of amylase from Penicillium olsonii under the effect of some antioxidant vitamins . Global J. of Biotechnology \& Biochemistry .3 (1): 14 -21. 
Akpan, I.; M.O. Bankole, and A.M. Adesemowo (1999) A rapid plate culture method for screening of amylase producing micro-organisms. Biotechnology Techniques 13: 411-413.

Alva, S., J. Anupama; J.Savla; Y. Y. Chiu; P. Vyshali; M. Shruti; B. S. Yogeetha; D. Bhavya; J. Purvi; K. Ruchi; B. S. Kumudini and K. N. Varalakshmi (2007) Production and characterization of fungal amylase enzyme isolated from Aspergillus sp. JGI 12 in solid state culture . African Journal of Biotechnology. 6 (5): 576-581.

Aquino, A.C.; J.A. Jorge; H.F. Terenza and M.L. Polizeli (2003) Studies on thermostable a-amylase from the thermophilic fungus Scytalidium thermophilum, Appl. Microbiol. Biotechnol. $61: 323-328$.

Aravantinos-Zafiris, G.; C. Tzia; V. Oreopoulou and C.D. Thomopoulos (1994) Fermentation of orange processing wastes for citric acid production, J. of Science and Food Agriculture. 65: 117-120 .

Arnesen, S.; S.H. Eriksen; J. Olsen and B. Jensen (1998) Increased production of amylase from Thermomyces lanuginosus by the addition of Tween 80, Enzyme Microb. Technol. 23: 249-252.

BBI International (2002) State of Maine Ethanol Pre-Feasibility Study Prepared for: Finance Authority of Maine 5 Community Drive P.O. Box 949, ME 04332-0949. P.O.Box 159 Cotopaxi, Colorado 81223 (719) 942-4353.

Bergmann,F.W.; Abe , J. and Hizukuri,S. (1988) : Selection of microorganims which produce raw starch degrading amylases. Appl. Microbiol. Biotechnol. 27: 443-446.

Bunni, L.; L. Mc Hale and A.P. Mc Hale (1989) Production, isolation and partial characterization of an amylase system produced by Talaromyces emersonii CBS 814.70, Enzyme Microb. Technol. 11: 370-375.

Carlsen, M.; A.B. Spohr; J. Nielsen and J. Villadsen (1996b) Morphology and physiology of an a-amylase producing strain of Aspergillus oryzae during batch cultivations, Biotechnol. Bioeng.49 266-276.

Carlsen, M.; J. Nielsen and J. Villadsen (1996 a) Growth and a-amylase production by Aspergillus oryzae during continuous cultivations, J. Biotechnol. 45: 81-93.

Carrizales, V. and W. Jappe (1986c) Solid-state fermentation: an appropriate Technology for developing countries. Intersciencia 11: 9-15.

Chadha, B.S. Singh, S.; Vohra, G. and Saini, H.S. (1997): Shake culture studies for the production of amylases by Thermomyces lanuginosus,Acta Microbiol. Immunol. Hung. 44: 181-185.

Delgado , R.; A.J. Castro and M. Vázquez (2009) enzymatic hydrolysis of potato. LWT- Food Science and Technology. 42 (4): 797-804. Or A kinetic assessment of the enzymatic hydrolysis of potato (Solanum tuberosum). Copyright (c) 2008 Swiss Society of Food Science and Technology Published by Elsevier Ltd.

Djekrif-Dakhmouche, S. ; Z. Gheribi-Aoulmi; Z. Meraihi and L. Bennamoun (2006) Application of a statistical design to the optimization of culture medium for a-amylase production by Aspergillus niger ATCC 16404 grown on orange waste powder, J. Food Eng. 73 : 190-197. 
Erratt, J.A., P.E. Douglas; F. Moranelli and V.L. Seligy (1984) The induction of a-amylase by starch in Aspergillus oryzae: evidence for controlled mRNA expression. Can. J. Biochem. Cell Biol. 62, 678-690.

Forgarty, W.M. (1983) Microbial amylase. In: Microbiol. And Biotechnol. Ed. Forgarty WM. Applied Science Publishers, Barking, U.K.: 1-92.

Francis, F.; A. Sabu; K.M. Nampoothiri; S. Ramachandran; S. Ghosh; G. Szakacs and A. Pandey (2003) Use of response surface methodology for optimizing process parameters for the production of amylase by Aspergillus oryzae. Biochem.Eng.J.15: 107-115.

Goto, C.E.; E.P. Barbosa; L.C.L Kistner; F.G. Moreira; V. Lenartovicz and R.M. Peralta, (1998) Production of amylase by Aspergillus fumigatus utilizing a-methyl-D-glucoside,a synthetic analogue of maltose,as substrate,FEMS Microbiol.Lett.167:139-143.

Gregg, D. and J.N. Saddler (1995) A technoeconomic assessment of the pretreatment and fractionation steps of a biomass to ethanol process. Appl.Biochem.Biotechnol.58:1261- 1282.

Hang, Y. D. and E. E. Woodams (1984) Apple Pomace: A potential substrate for citric acid production by Aspergillus niger, Biotechnology Letters. 6: 763-764.

Hang, Y. D. and E. E. Woodams (1985) Grape Pomace: A novel substrate for microbial production of citric acid, Biotechnology Letters.7 : 253-254 .

Hang, Y. D. and E. E. Woodams (1987) Microbial production of citric acid by solid state fermentation of Kiwi fruit peel, J. of Food Science.52 : 226227.

Haq, I.; T.S. Khan; M.M. Javed and Mukhtar, H.(2006) : Consortia of Aspergillus niger and Trichoderma viride and Bio-Synthesis of GlucoAmylase. Journal of Applied Sciences Research, 2(9): 553-558,

Hayashida , S ; Y. Teramoto and T. Inove (1988) Production and characteristics of raw-potato starch digesting a-amylase from Bacillus substilis 65. Appl. Environ. Microbiol. 54:1516-1522.

Hayashida, S. and Y. Teramoto (1986) Production and characteristics of rawstarch-digesting a-amylase from a protease negative Aspergillus ficuum mutant, Appl. Environ. Microbiol. 52: 1068-1073.

Hegazy, E.S. (2009) Seed potato production in Egypt. Agrofood co. Cairo Egypt.ww.unece.org/trade/agr/meetings/ge.../Egypt.../S4_SalahHegaz y.pdf Email: Salah@agrofood.com.eg

Huang, L.P.; B. Jin; P. Lant and J.T. Zhou (2003) Biotechnological production of lactic acid integrated with potato wastewater treatment by Rhizopus arrhizus, J. Chem. Technol. Biotechnol. 78: 889- 906.

Huang, L.P.; B. Jin; P. Lant and J. Zhou (2005) Simultaneous saccharification and fermentation of potato starch wastewater to lactic acid by Rhizopus oryzae and R. arrhizus. Biochemical Engineering Journal.23:265-276 .

Ibukun E.O.; F. Akindumila (1998) Extracellular amylase production by isolates of Bacilli microorganism cultured on different starchy food broths . Nig.J. Biochem. Mol.Biol. 13: 91-95 
Darwish, Soumia M. I. et al.

Jensen, B. and J. Olsen (1992) Physicochemical properties of a purified alpha amylase from the thermophilic fungus Thermomyces lanuginosus ,Enzyme Microb.Technol.14:112-116

Jin, B.; J.L. van.; B. Patel; H. Doelle and Q. Yu (1999) Production of fungal protein and glucoamylase by Rhizopus oligosporus from starch processing waste water, Process Biochem. $34: 59-65$.

Kammoun ,R.; B. Naili and B. S. Samir (2008) Application of a statistical design to the optimization of parameters and culture medium for aamylase production by Aspergillus oryzae CBS 819.72 grown on gruel (wheat grinding by-product) Bioresource Technology 99 : 5602-5609.

Kaneko, A.; S. Sudo; Y. Takayasu-Sakamoto; G. Tamura; T. ;Ishikawa and T. Oba (1996) Molecular cloning and determination of the nucleotide sequence of a gene encoding an acid-stable a-amylase from Aspergillus kawachii, J. Ferment. Bioeng. 81: 292-296.

Kaur , P. and J. T. Worgan (1982) Lipid production by Aspergillus oryzae from starch substrates.Applied Microbiology and Biotechnology.16(23):126-130.

Khan, K. H ; N. Ahmed; J. K. Sial, and M. I. Khan. (1996) Ground water pollution by heavymetals. Sci. Tech. Dev. 14:1 - 5 .

Khare, S. K., K. Jha and A. P. Gandhi (1995) Short communication: citric acid production from Okara (Soy-residue) by solid-state fermentation, Bioresource Technology, 54 : 323-325

Kunamneni,A.; S.K. Kuttanpillai; and S. Singh (2005) Response surface methodological approach to optimize the nutritional parameters for enhanced production of a-amylase in solid--state fermentation by Thermomyces lanuginosus, Afr. J. Biotechnol.4 : 708-716.

Liu, X. and Y. Xu (2008) A novel raw starch digesting a-amylase from a newly isolated Bacillus sp.YX-1:Purification and characterization.Bioresource Technology .99:4315-4320.

Miller, G.L. (1959) Use of dinitrosalicylic acid reagent for determination of reducing sugar, Anal. Chem. 31 (3): 426-428.

Mona Gouda and Elbahloul, Y. (2008) :Statistical Optimization and Partial Characterization of Amylases Produced by Halotolerant Penicillium Sp. World Journal of Agricultural Sciences. 4 (3): 359-368 .

Moreira, F.G. ; Lenartovicz, V.L. and Peralta, R.M. (2004) : A thermostable maltose-tolerant a-amylase from Aspergillus tamari, J.Basic Microbiol.44:29-35.

Nguyen, Q.D. ; J.M. Rezessy-Szabo and A. Hoschke (2000) Optimisation of composition of media for the production of amylolytic enzymes by Thermomyces lanuginosus ATCC 34626, Food Technol. Biotechnol. 38 229-234.

Okolo, B.N.; L.I. Ezeogu and C.N. Mba (1995) Production of raw starch digesting amylase by Aspergillus niger grown on native starch sources, J. Sci. Food Agric.69:109-115.

Omemu, A.M., I. Akpan; M.O. Bankole; and O.D. Teniola (2005) Hydrolysis of raw tuber starches by amylase of Aspergillus niger AM07 isolated from the soil. African Journal of Biotechnology. 4: 19-25. 
Pandey, A. (1991) Effect of particle size of substrate on enzyme production in solid-state fermentation, Bioresour. Technol. 169-172.

Pandey, A. (1992) Recent process developments in solid-state fermentation ,Process Biochem. 27: 109-117.

Pandey, A. and V.T. Soccol (2000) Soccol, Biopotential of immobilized enzymes, Indian J. Microbiol. 40: 1-14.

Pandey, A.; C.R. Soccol; J.A. Rodriguez-Leon and P. Nigam (2001) Solid state fermentation in biotechnology: fundamentals and applications, asiatech . Publishers Inc., New Delhi, India. 3-7.

Pandey, A.; P. Nigam; C.R. Soccol; V.T. Soccol; D. Singh, and R. Mohan (2000a) Advances in microbial amylases (review). Biotechnol. Appl. Biochem.31: 135-152.

Pandey, A.; P. Nigam; C.R. Soccol; V.T. Soccol; D. Singh, and R. Mohan (2000b) : Biotechnological potential of agro-industrial residues. II. Cassava bagasse, Bioresource Technology, 74: 81-87.

Pandey, A.; P. Selvakumar; C.R. Soccol and P. Nigam (1999) Solid-state fermentation for the production of industrial enzymes,Curr. Sci.77:149_ 162

Patel, A.K. ; Nampoothiri, K.M. ; S. Ramachandran; G. Szakacs; A. Pandey and A. Partial (2005) purification and characterization of a-amylase produced by Aspergillus oryzae using spent brewing grains, Indian $\mathrm{J}$. Biotechnol. 4: 336-342.

Pederson, H. and J. Nielson (2000) The influence of nitrogen sources on the a-amylase productivity of Aspergillus oryzae in continuous cultures, Appl. Microbiol. Biotechnol. 53: 278- 281.

Presscott , S.C. and C.G. Dunn (1959) The citric acid fermentation, In Industrial Microbiology, McGraw Hill Book Co., New York.

Rahardjo, Y.S.P.; S. Sie; F.J. Weber; J. Tramper and A. Rinzema (2005) Effect of low oxygen concentrations on growth and a-amylase production of Aspergillus oryzae in model solid-state fermentation systems, Biomol. Eng. 21: 163-172. 16. Y.S.P.

Rojas , J.A. ; C. Cruz; F.J. Mika; L.V. Villalba; Marı ; C. Cepero de Garcı and S. Restrepo (2008) Isoenzyme characterization of proteases and amylases and partial purification of proteases from filamentous fungi causing biodeterioration of industrial paper. International Biodeterioration \& Biodegradation xxx: 1-7.

Samborska, K.; Y. Guiavarch; A. Van Loey and M. Hendrickx (2005) The influence of moisture content on the thermostability of Aspergillus oryzae a-amylase, Enzyme Microb. Technol. 37: 167-174.

Schwab,K. ; C. Brokamp; C. Weigel and M.K. Popovic (2007) Production and Characterization of $\alpha$-amylase. Journal of Biotechnology, doi: 10 (1016): 07.234.

Smith,D. and A.H.S. Onnions (1983a) The preservation and maintenance of living fungi . Kew,Surrey : Commonwealth Myco`logical Institute .

Smith,D. and A.H.S. Onnions (1983b) A'comparison of some preservation techniques for fungi.Trans Br. Mycol. Scie. 81: 535-540. 
Soccol, C. R., F. C. Prado; L. P. S. Vandenberghe and A. Pandey (2003) General aspects in citric acid production by submerged and solid-state fermentation.: Encyclopedia on Bioresource Technology. Haworth Press, New York:, 652-664.

Sudo, S.; T. Ishikawa; K. Sato and T. Oba (1995) Comparison of acid-stable a-amylase production by Aspergillus kawachii in solid-state and submerged culture, J. Ferment. Bioeng. 77: 483-489.

Tomas, L.C. and G.J. Chamberlain (1980) Colorimetric chemical analytical methods, Tintometer Ltd., Salisbury, UK, 3-5.

Ueda, S. (1981) Fungal gluco-amylases and raw starch digestion. TIBS March : 89-90.

USDA/Agricultural Research Service (2008) : Sweet potato out-yields corn in ethanol production study. Science Daily.

Vandenberghe, L. P. S., C. R. Soccol; A. Pandey and J.M. Lebeault (2000b) Solid-state fermentation for the synthesis of citric acid by Aspergillus niger, Bioresource Technology, 74 : 175-178.

Vandenberghe, L. P. S.; C. R. Soccol; A. Pandey and J. M. Lebeault (2000a) Cassava Bagasse, an alternative substrate for citric acid production in solid-state fermentation.In:11th International Biotechnology Symposium and Exhibition,3-8Sept.,Berlin.Book of Abstracts.Frankfurt: Dechema,4, 153-155.

Vishwanathan, P. and N.R. Surlikar (2001) Production of a-amylase with Aspergillus flavus on Amaranthus grains by solid-state fermentation,J. Basic Microbiol. 41: 57-64.

Yabuki , M. ; N. Ono; K. Hoshino and S. Fukui (1977) Rapid induction of amylase by non growing mycelia of Aspergillus oryzae. Appl. Environ. Microbial. 34: 1-6.

Yamasaki, Y.; A. Tsuboi, and Y. Suzuki (1977) Two forms of glucoamylases from Mucor rouxianus: properties of two glucoamylases. Agric. Biol. Chem. 41: 2139-2148.

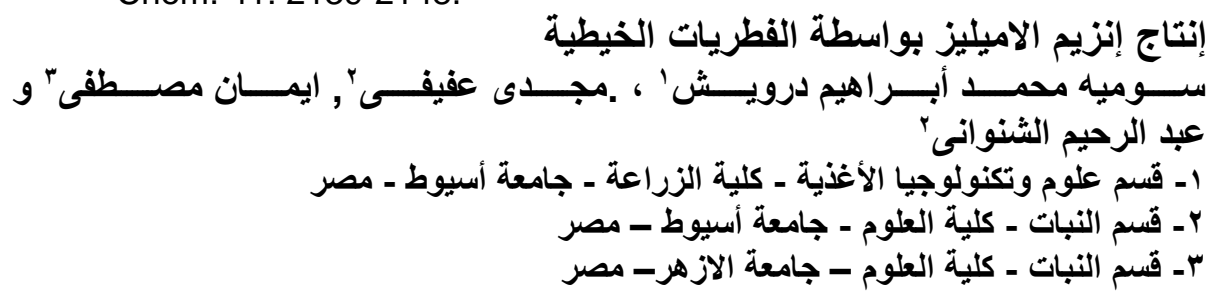

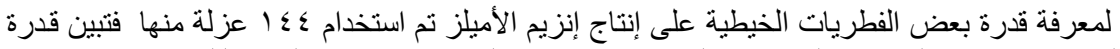

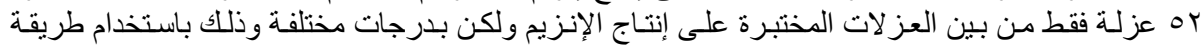

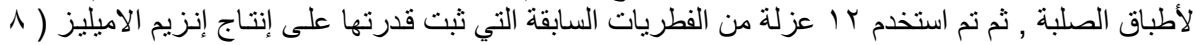

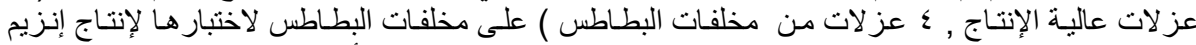

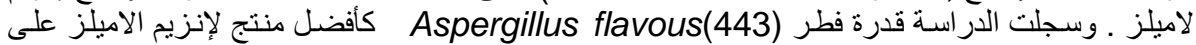

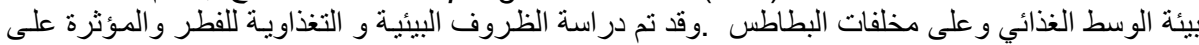

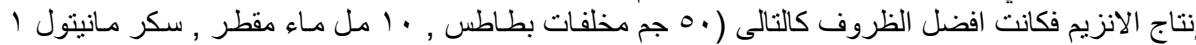

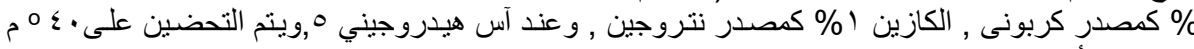


Table (IV): Optimization and Maximization of Both Nutrition and Environmental Factors Affecting Amylase Enzymes Production by Aspergillus flavus (443) as highly Producer Strain Tested On Potato Wastes.

\begin{tabular}{|c|c|c|c|c|c|c|c|c|c|c|c|c|c|c|c|c|c|}
\hline \multicolumn{9}{|c|}{ Environmental factors } & \multicolumn{9}{|c|}{ Nutritional factors } \\
\hline \multicolumn{3}{|c|}{ Incubation period } & \multicolumn{3}{|c|}{ pH values } & \multicolumn{3}{|c|}{$\begin{array}{l}\text { Incubation } \\
\text { temperature }\end{array}$} & \multicolumn{3}{|c|}{ Nitrogen sources } & \multicolumn{3}{|c|}{ Carbon source } & \multicolumn{3}{|c|}{$\begin{array}{c}\text { Amount of } \\
\text { substrate used }\end{array}$} \\
\hline Days & ${ }^{\star} R . S$. & \begin{tabular}{|l|}
${ }^{\star \star} \mathrm{M}$. \\
d. $c . z$
\end{tabular} & $\mathrm{pH}$ & ${ }^{*}$ R.S. & \begin{tabular}{|l|}
${ }^{\star *} \mathrm{M}$. \\
d. $c . z$
\end{tabular} & $\circ \mathbf{C}$ & ${ }^{\star}$ R.S. & \begin{tabular}{|l|}
${ }^{\star \star} \mathrm{M}$. \\
d. $c . z$
\end{tabular} & Name & ${ }^{*}$ R. S. & $\begin{array}{c}{ }^{\star \star} M . d . \\
\text { c .z }\end{array}$ & Name & ${ }^{\star}$ R.s. & \begin{tabular}{|l|}
${ }^{\star \star} \mathrm{M}$. \\
d. $\mathrm{C} . z$
\end{tabular} & gm & *R.s. & $\begin{array}{c}{ }^{\star \star} \text { M. d. } \\
\text { c .z }\end{array}$ \\
\hline 3 & 0.234 & 27 & 3 & 0.722 & 19.8 & 10 & 0.754 & 18.75 & Peptone & 0.650 & 22.1 & Lactoe & 1.056 & 16.1 & 1 & 0.722 & 20.0 \\
\hline 5 & 0.276 & 25.5 & 4 & 0.714 & 20.0 & 20 & 0.630 & 22.5 & Urea & 0.440 & 24.5 & Fructose & 1.200 & 12.0 & 2.5 & 0.650 & 22.0 \\
\hline \multirow[t]{7}{*}{7} & 0.298 & 25.0 & 5 & 0.448 & 24.5 & 30 & 0.480 & 23.12 & $\begin{array}{l}\text { Ammonium } \\
\text { phosphate }\end{array}$ & 0.658 & 21.75 & Glucose & 1.216 & 11.5 & 5 & 0.640 & 22.3 \\
\hline & & & 6 & 0.710 & 20.3 & 40 & 0.294 & 25.12 & Amonium sulphate & 0.432 & 24.7 & Maltose & 1.088 & 15.3 & 15 & 0.228 & 27.3 \\
\hline & & & 7 & 0.714 & 20.2 & 50 & 1.040 & 16.5 & Casine & 0.276 & 25.5 & Manitol & \begin{tabular}{|l|}
0.202 \\
\end{tabular} & 28.0 & 25 & 0.218 & 27.5 \\
\hline & & & 8 & 0.718 & 20.1 & 60 & 1.060 & 16.0 & & & & Sucrose & \begin{tabular}{|l}
0.702 \\
\end{tabular} & 25.5 & 50 & \begin{tabular}{|l|}
0.202 \\
\end{tabular} & 28.0 \\
\hline & & & 9 & 0.722 & 20.0 & & & & & & & Starch & 1.200 & 12.0 & & & \\
\hline & & & 10 & 0.686 & 21.0 & & & & & & & & & & & & \\
\hline & & & 11 & 1.060 & 16.0 & & & & & & & & & & & & \\
\hline
\end{tabular}

${ }^{\star}$ R.s. $\quad=$ Residue of the reducing sugars in the culture medium (g/l)

${ }^{\star \star} M$. d. $\mathbf{c} . \mathrm{z}=$ Mean diameters of clearing zone $(\mathrm{mm})$ 